\title{
Carcass Composition, Meat Quality and Sensory Quality of Gentile di Puglia Light Lambs: Effects of Dietary Supplementation with Oregano and Linseed
}

\author{
Giuseppe Scarpa ${ }^{1}$, Simona Tarricone ${ }^{2, *}$ (1) and Marco Ragni ${ }^{2}$ \\ 1 Ministry of Agricultural, Food and Forestry Policies, Central Inspectorate Department for Quality Control \\ and Agri-Food Fraud Repression, Branch Office of Bari, 70126 Bari, Italy; g.scarpa@politicheagricole.it \\ 2 Department of Agricultural and Environmental Science, University of Bari Aldo Moro, 70125 Bari, Italy; \\ marco.ragni@uniba.it \\ * Correspondence: simona.tarricone@uniba.it
}

Citation: Scarpa, G.; Tarricone, S.; Ragni, M. Carcass Composition, Meat Quality and Sensory Quality of Gentile di Puglia Light Lambs: Effects of Dietary Supplementation with Oregano and Linseed. Animals 2021, 11, 607. https://doi.org/10.3390/ ani11030607

Academic Editors: José Luis Guzmán-Guerrero, Manuel Delgado-Pertíñez and Ignacio Martín-García

Received: 13 January 2021

Accepted: 22 February 2021

Published: 25 February 2021

Publisher's Note: MDPI stays neutral with regard to jurisdictional claims in published maps and institutional affiliations.

Copyright: (c) 2021 by the authors. Licensee MDPI, Basel, Switzerland. This article is an open access article distributed under the terms and conditions of the Creative Commons Attribution (CC BY) license (https:/ / creativecommons.org/licenses/by/ $4.0 /)$.
Simple Summary: This study characterizes the carcass composition, meat quality, and sensory attributes of an Italian native ovine breed. This investigation aims to implement feeding strategies in light lambs to enhance healthier fatty acids in meat; this is possible by applying extruded linseed and extruded linseed + oregano in a total mixed ration. The dietary treatments have no significant effect on the growth performances, slaughtering data, carcass composition, and quality meat. Moreover, meat chemical composition is not affected by feed supplementation. The diet supplemented with linseed + oregano appears to reduce the concentration of saturated fatty as well as the $n-6 / n-3$ ratio. Due to these changes, meat fatty acid profile is improved, and so are the lamb meat healthy properties. Consequentially, the obtained good sensory traits are compatible with the requirements of the market's consumer. The combination of nutritional and sensory traits, with properties related to human health that is presented by these native light lambs, qualifies this production as a good choice of red meat to be included in a larger proportion in human food.

Abstract: There is a growing demand by the modern consumer for meat containing less fat and lower levels of saturated fatty acids, which are considered to increase the risk of coronary heart disease. In southern Italy, the Gentile di Puglia breed is one of the most common on farms, and the light lambs are often consumed. The study evaluates the effect of a diet containing extruded linseed (Linum usitatissimum) on growth performances, carcass traits, and meat quality in Gentile di Puglia light lambs. Thirty-six male lambs are weaned at about 20 days of age, and divided into three groups - each group is either fed a control diet (C), a diet containing 3\% extruded linseed (L), or a diet containing 3\% extruded linseed and $0.6 \%$ oregano (Origanum vulgare) $(\mathrm{L}+\mathrm{O})$. The lambs' growth performances and the slaughtering and dissection data did not differ between groups. Dietary treatments have no significant effect on the quality and chemical composition of Longissimus lumborum (Ll). The mount of linoleic acid in $\mathrm{Ll}$ meat is significantly higher in the L group, and this positively affected the total content of n-3 Polyunsaturated Fatty Acid, as well as the n-6/n-3 ratio. The good results obtained concerning the sensory traits meet the requirements of the market's consumer.

Keywords: lambs; Gentile di Puglia; linseed; oregano; meat quality; fatty acid; sensory quality

\section{Introduction}

The Gentile di Puglia is an Italian ovine breed created in the 15th century from a cross between Merino Spanish rams and "Gentile" ewes reared in some areas of Southern Italy, mainly Apulia and Basilicata [1]. After the Second World War, the consistency of its population exceeded one million heads. At the beginning of the $60^{\prime}$ s, the dramatic reduction of its population was determined by many factors [2]. To maintain their market 
shares, and therefore, their livelihood, Gentile di Puglia breeders began the task of crossing their animals with meat and milk sheep breeds according to their short-term production needs. A large number of animals derived from the Gentile di Puglia converged into a new genetic type named "Merinizzata Italiana", which contributes to a further decline of the breed. Nowadays, with only 7.200 existing animals, the Gentile di Puglia population is considered endangered according to EU parameters [3,4]. It seems appropriate, in such a situation, to reassess the typical products of the breed and to introduce safeguards to avoid its extinction. In the South of Italy, light lamb's meat is the main kind of sheep meat appreciated by the consumer. All ruminant's meat contains a favorable proportion of fatty acids, including the long-chain n-3 fatty acids [5]; nevertheless, lamb and beef meat have been associated with an increased risk of cardiovascular disease due to their high content of saturated fatty acids (SFA) [6]. The formation of large SFA is a result of the biohydrogenation process in the rumen during which bacteria convert unsaturated fatty acids (UFA) to SFA. Therefore, the fatty acids occurring in the rumen are highly saturated and take part in the absorption, as well as deposition of the fat in muscles.

The supplementation of ruminant diets with lipid sources rich in polyunsaturated fatty acids (PUFA) is an effective strategy to improve the nutritional value of meat fat; This diet decrease SFA and enriches PUFA, including the health-enhancing fatty acids (FA), such as conjugated linoleic acid (CLA) and n-3 PUFA [7]. In the last decade, several attempts have been made to increase the PUFA level in meat from livestock species, including dietary supplementation with linseed and linseed oil in lambs [8-11], kids [12,13], steers [14,15], and pigs [16]. However, increased PUFA level may limit the shelf-life of meat, because they are more prone to oxidation [17]. Antioxidants can be used to prevent or inhibit oxidation; supplementation of ruminants' diets with natural antioxidants is considered an effective strategy for modulating and improving the fatty acid composition of meat [18], milk, and fresh cheese [19]. Natural antioxidants, such as oregano, sage, thyme, and rosemary, are well accepted by consumers, because they are considered safe and healthy [20,21]. The antioxidant activity in oregano is mainly attributed to carvacrol and thymol [22]; these molecules make the bacterial cell membrane permeable [23], and convert lipids and hydroxyl radicals into stable products [24]. Studies on oregano (Origanum vulgare) supplied in lambs' diet have confirmed its effectiveness in enhancing oxidative stability in meat, as well as in improving its sensory quality $[25,26]$. Nevertheless, there is little information about the effects of the combination of oregano with linseeds on lamb meat, taking into account that oregano could improve the oxidative stability of meat enriched in unsaturated FA due to the use of linseeds in the diet.

Therefore, the aim of this study was conducted to compare the effect of dietary supplementation with oregano and extruded linseed on growth performances and meat quality of Gentile di Puglia light lambs.

\section{Materials and Methods}

\subsection{Animal Management and Diet}

The study was carried out at the farm "Di Trani" located in Grumento Nova (PZ), Basilicata region, Italy (Latitude $40.281628 \mathrm{~N}$, Longitude $15.896160 \mathrm{E} ; 650 \mathrm{~m}$ asl). It involved 36 male Gentile di Puglia breed lambs. Lambs were reared according to the traditional farming system for the Gentile di Puglia breed as they were exclusively milk-fed, suckling from the ewes until they reached the age of about 20 days. Then lambs were divided into three groups of twelve animals each, homogeneous regarding age (20 \pm 3 days old) and initial live weight $(9.50 \pm 0.25 \mathrm{~kg})$. Each group was assigned to one of the following dietary treatments: C — control group, that received a commercial pelleted feed; L-group fed a pelleted feed containing 3\% extruded linseed (Linum usitatissimum L.); and LO-group fed a pelleted feed containing 3\% extruded linseed and $0.6 \%$ dried oregano (Origanum vulgare L.) inflorescences. The three pelleted total mixed rations were formulated to be isocaloric and isonitrogenous, and to meet or exceed the nutritional requirements of lambs [27] (Table 1). 
Table 1. Composition of the experimental diets.

\begin{tabular}{cccc}
\hline \multirow{2}{*}{ Ingredients (\% As-fed Basis) } & \multicolumn{3}{c}{ Dietary Treatment $^{\mathbf{1}}$} \\
\cline { 2 - 4 } & $\mathbf{C}$ & $\mathbf{L}$ & $\mathbf{L}+\mathbf{O}$ \\
\hline Corn & 31.00 & 31.00 & 30.40 \\
Faba bean & 10.00 & 8.50 & 8.50 \\
Wheat bran & 10.00 & 10.00 & 10.00 \\
Barley & 9.00 & 9.00 & 9.00 \\
Wheat flour shorts & 9.00 & 9.00 & 9.00 \\
Sunflower meal & 8.00 & 7.50 & 7.50 \\
Dehulled soybean & 6.00 & 6.00 & 6.00 \\
Sugar beet pulp & 6.00 & 6.00 & 6.00 \\
Soybean hulls & 4.00 & 4.00 & 4.00 \\
Molasses & 3.00 & 3.00 & 3.00 \\
Vitamin-mineral premix & 3.00 & 3.00 & 3.00 \\
Soybean oil & 1.00 & - & - \\
Extruded linseed & - & 3.00 & 3.00 \\
Oregano (dried inflorescences) & - & - & 0.60 \\
\hline
\end{tabular}

${ }^{1} \mathrm{C}$, control feed; $\mathrm{L}$, control feed $+3 \%$ extruded linseed; $\mathrm{LO}$, control feed $+3 \%$ extruded linseed $+0.6 \%$ oregano.

The lambs were housed in individual pens $\left(0.8 \mathrm{~m}^{2} /\right.$ head $)$ with free access to water, and the temperature in pens ranged from 7 to $15^{\circ} \mathrm{C}$. Each animal received feeding ad libitum, and his daily consumption was recorded daily. Each week lambs were weighed to calculate the average daily gain (ADG) until they were slaughtered at 60 days of age; this was done by exsanguination, according to the official veterinary rules after fasting for $12 \mathrm{~h}$, with free water access, and recording the body weight. The hot carcass, skin, fleece, pluck, and full and empty gastrointestinal tract were weighed. Carcasses were hung and chilled at $4{ }^{\circ} \mathrm{C}(80-82 \%$ relative humidity) for $24 \mathrm{~h}$ and then weighed. The $\mathrm{pH}$ values were measured in the Longissimus lumborum (Ll) muscle at the time of slaughter (pH1) and after $24 \mathrm{~h}(\mathrm{pH} 24)$ under refrigerated conditions $\left(4^{\circ} \mathrm{C}\right)$, using a portable instrument (Model HI 9025; Hanna Instruments, Woonsocket, RI, USA) with an electrode (FC 230C; Hanna Instruments) and performing a two-point calibration ( $\mathrm{pH} 7.01$ and 4.01).

The refrigerated carcasses were split into two halves by the mid-line; the right side was divided into different cuts (neck, shoulder, leg, steaks, brisket) and weighed separately. The loin was transported from the slaughterhouse to the laboratory under refrigerated conditions. The meat cuts were stored at $4{ }^{\circ} \mathrm{C}$ for a further $24 \mathrm{~h}$ and then dissected into tissue components (lean, dissectible fat, and bone), and the weight of each tissue was recorded [28].

\subsection{Chemical Composition of Feed}

Representative samples of the pelleted feeds were taken every 20 days, and mixed to obtain a single final pool for each diet, which was then analyzed to determine the chemical composition and fatty acid profile (Table 2). Samples were ground in a hammer mill with a 1-mm screen and analyzed using the following Association of Official Agricultural Chemistry AOAC [29] procedures: Dry matter (method 934.01), ether extract (method 920.39), ash (method 942.05), crude protein (method 954.01), crude fiber (method 945.18), ADF and ADL (method 973.18), and amylase-treated neutral detergent fiber (NDF) (method 2002.04). Metabolizable energy was calculated using INRA system [30]. 
Table 2. Chemical and fatty acid composition of diets.

\begin{tabular}{cccc}
\hline Variable & \multicolumn{3}{c}{ Dietary Treatment $^{\mathbf{1}}$} \\
\cline { 2 - 4 } & $\mathbf{C}$ & $\mathbf{L}$ & $\mathbf{L}+\mathbf{O}$ \\
\hline Chemical composition (\% on DM basis) & & & \\
Crude protein & 15.51 & 15.60 & 15.61 \\
Ether extract & 3.66 & 3.70 & 3.71 \\
Ash & 3.41 & 3.49 & 3.56 \\
Crude fiber & 7.91 & 7.92 & 8.32 \\
NDF 2 & 21.19 & 21.24 & 21.15 \\
ADF 2 & 9.58 & 9.56 & 9.53 \\
ADL 2 & 1.79 & 1.86 & 1.85 \\
ME (MJ) & 10.16 & 10.18 & 10.05 \\
Fatty acid composition (\% FA methyl esters) & & & \\
C16:0 (palmitic) & 9.23 & 7.47 & 7.39 \\
C18:0 (stearic) & 1.18 & 3.55 & 4.08 \\
C18:1 n-9, cis 9 (oleic) & 17.78 & 18.76 & 17.99 \\
C18:2 n-6 (linoleic) & 15.16 & 22.15 & 20.42 \\
C18:3 n-3 ( $\alpha$-linolenic) & 4.65 & 31.00 & 30.68 \\
C22:5 n-3 (DPA) & 0.46 & 0.17 & 0.27 \\
C22:6 n-3 (DHA) & 0.29 & 0.28 & 0.28 \\
\hline
\end{tabular}

${ }^{1} \mathrm{C}$, control feed; $\mathrm{L}$, control feed $+3 \%$ extruded linseed; $\mathrm{LO}$, control feed $+3 \%$ extruded linseed $+0.6 \%$ oregano

${ }^{2} \mathrm{NDF}$, neutral detergent fiber; ADF, acid detergent fiber; ADL, acid detergent lignin.

\subsection{Physical Parameters of Longissimus lumborum Muscle}

On sample muscles meat color and tenderness were determined. Meat color $\left(\mathrm{L}^{*}=\right.$ lightness, $\mathrm{a}^{*}=$ redness, $\mathrm{b}^{*}=$ yellowness $)$ was determined using a Hunter Lab MiniscanTM XE Spectrophotometer (Model 4500/L, 45/0 LAV, $3.20 \mathrm{~cm}$ diameter aperture, $10^{\circ}$ standard observer, focusing at $25 \mathrm{~mm}$, illuminant D65/10; Hunter Associates Laboratory Inc., Reston, VA, USA). Three readings were taken for each sample by placing the instrument on different meat areas. The instrument was normalized to a standard white tile before performing the analysis $(\mathrm{Y}=92.8, \mathrm{x}=0.3162$, and $\mathrm{y}=0.3322)$. The reflectance measurements were performed after the samples were allowed to oxygenate in the air for at least $30 \mathrm{~min}$, to take stable measurements [31]. Three samples $(1.25 \mathrm{~cm}$ diameter and thick) of each muscle were tested for tenderness by the Warner-Bratzler Shear (WBS) force system using an Instron 5544 testing machine. Shear forces were determined perpendicular to the fiber direction.

\subsection{Chemical Composition and Fatty Acid Analyses of Longissimus Lumborum Muscle}

To analyze the chemical composition of meat, representative sub-samples of $\mathrm{Ll}$ muscles were homogenized, and AOAC procedures were used to assess moisture, ether extract, raw protein, ash [29].

Fat was extracted according to the method suggested by Folch et al. [32], using a 2:1 chloroform/methanol $(v / v)$ solution to determine the fatty acid profile. The fatty acids were then methylated using a $\mathrm{KOH} /$ methanol $2 \mathrm{~N}$ solution [33], and analyzed by gas chromatography (Shimadzu GC-17A) using a silicone-glass capillary column (70\% Cyanopropyl Polysilphenylene-siloxane BPX 70 by Thermo Scientific (Pittsburgh, PA, USA), length $=60 \mathrm{~m}$, internal diameter $=0.25 \mathrm{~mm}$, film thickness $=0.25 \mu \mathrm{m}$ ). The starting temperature was $135^{\circ} \mathrm{C}$ for $7 \mathrm{~min}$, then it was increased by $4{ }^{\circ} \mathrm{C} / \mathrm{min}$ up to $210^{\circ} \mathrm{C}$. Samples of each concentrate mixture were used for fatty acid analysis according to the method described above for meat fatty acid profile. Fatty acids were expressed as a percentage $(w t / w t)$ of total methylated fatty acids.

The food risk factors of meat were determined by calculating the Atherogenic (AI) and Thrombogenic (TI) Indices [34]:

$$
\mathrm{AI}=[(\mathrm{C} 12: 0+4 \times \mathrm{C} 14: 0+\mathrm{C} 16: 0)] \div[\Sigma \mathrm{MUFA}+\Sigma \mathrm{n}-6+\Sigma \mathrm{n}-3] ;
$$




$$
\mathrm{TI}=[(\mathrm{C} 14: 0+\mathrm{C} 16: 0+\mathrm{C} 18: 0)] \div[(0.5 \times \Sigma \mathrm{MUFA}+0.5 \times \Sigma \mathrm{n}-6+3 \times \Sigma \mathrm{n}-3+\Sigma \mathrm{n}-3) / \Sigma \mathrm{n}-6] ;
$$

where MUFA are monounsaturated fatty acids.

Lipid oxidation was evaluated in Longissimus lumborum muscle samples stored at $4{ }^{\circ} \mathrm{C}$ for $48 \mathrm{~h}$ after slaughtering by measuring the concentration of 2-thiobarbituric acid reactive substances (T-BARS) [35], and expressed as mg malondialdehyde (MDA) $/ \mathrm{kg}$ meat.

\subsection{Sensorial Analysis}

The sensorial analysis was performed according to procedures described by Landim et al. [36]. The $\mathrm{Ll}$ muscle at the 13th rib was used. Briefly, samples were cut in $1 \mathrm{~cm}^{3}$ cube and roasted in a preheated oven to $170{ }^{\circ} \mathrm{C}$. They remained there until the meat temperature was $71{ }^{\circ} \mathrm{C}$ at the geometric center of the cube. Forty-one non-trained judges indicated the intensity of sensation on a 9-point scale. Each judge received the meat in plastic containers coded with random three-digit numbers. Between tasting the three samples, each taster received a glass of water at room temperature and a cracker-type biscuit, to remove the residual taste from their mouth. The analysis was based on five sensory descriptors (Table 3); each descriptor was evaluated using a 9-point hedonic scale semi-structured and continuously anchored at extremities with terms that express intensity.

Table 3. Descriptors used in the quantitative descriptive sensory analysis of lamb meat.

\begin{tabular}{|c|c|}
\hline Descriptor & Definition \\
\hline Lamb flavor ${ }^{a}$ & $\begin{array}{c}\text { Mixed experience of olfactory, gustatory, and tactile sensations perceived during the tasting. Flavor intensity of } \\
\text { cooked lamb. }\end{array}$ \\
\hline Succulence ${ }^{\mathrm{b}}$ & The first perception of the quantity of liquid liberated by the sample of meat in the mouth. \\
\hline Tenderness ${ }^{c}$ & The force required to compress a piece of meat between the molar teeth, evaluated at the first bite \\
\hline Juiciness $^{\mathrm{d}}$ & Perception of the amount of liquid released from the meat sample in the mouth after fifth bite. \\
\hline Overall acceptance ${ }^{\mathrm{e}}$ & Sum of quality attributes that will contribute to determining the degree of product acceptance by panelists. \\
\hline
\end{tabular}

${ }^{\mathrm{a}} 0=$ not detected, $9=$ very intense; ${ }^{\mathrm{b}} 0=$ extremely dry, $9=$ extremely succulent; ${ }^{\mathrm{c}} 0=$ very tough, $9=$ very tender; ${ }^{\mathrm{d}} 0=$ very dry, $9=$ very juicy;

e $0=$ very bad, $9=$ very good.

\subsection{Statistical Analysis}

A completely randomized design with three treatments (diets) and twelve replicates (lambs) was used for the study. Data were analyzed using a GLM procedure of SAS software [37] with treatment (diet) as the fixed effect:

$$
Y_{i j}=M+A_{i}+E_{i j}
$$

where $Y_{i j}=$ analyzed trait of lambs or meat; $M=$ overall mean; $A_{i}=$ fixed effect of diet; $E_{i j}$ $=$ residual error.

When the diet effect was significant $(p<0.05)$, means were separated and compared by Tukey's HSD. Significance has been declared at $p<0.05$; results are reported as least squares mean and their standard error of the mean (SEM).

\section{Results and Discussion}

\subsection{Performance In Vivo and Post-Mortem of Lambs}

No significant differences were found for in vivo performances of lambs (Table 4), diets did not influence lambs' body weight after 20 and 40 days of trial, but their weight is similar to the weight recorded by Colonna et al. [9]. The ADGs did not show statistical significance; moreover, supplementation of lamb diet with oregano did not show the effect on growth and feed intake; our results are similar to Lestingi et al. [38], even though they used other experimental diets with Gentile di Puglia lambs. 
Table 4. Effect of diet on in vivo performances of lambs *.

\begin{tabular}{|c|c|c|c|c|c|}
\hline \multirow{2}{*}{ Item } & \multicolumn{3}{|c|}{ Dietary Treatment ${ }^{1}$} & \multirow{2}{*}{ SEM $^{2}$} & \multirow{2}{*}{$p$-Value } \\
\hline & $\mathrm{C}$ & $\mathbf{L}$ & $\mathrm{L}+\mathrm{O}$ & & \\
\hline Initial-20 d BW ${ }^{3}(\mathrm{~kg})$ & 9.39 & 9.81 & 9.42 & 0.923 & 0.911 \\
\hline $40 \mathrm{~d}$ BW $(\mathrm{kg})$ & 13.86 & 13.93 & 13.91 & 1.557 & 0.335 \\
\hline $60 \mathrm{~d} \mathrm{BW}(\mathrm{kg})$ & 19.53 & 19.03 & 19.30 & 2.220 & 0.125 \\
\hline Average daily BW gain $20-40(\mathrm{~kg} / \mathrm{d})$ & 0.223 & 0.206 & 0.224 & 0.044 & 0.074 \\
\hline Average daily BW gain 40-60 (kg/d) & 0.258 & 0.232 & 0.245 & 0.054 & 0.985 \\
\hline Average daily BW gain 20-60 (kg/d) & 0.241 & 0.219 & 0.235 & 0.042 & 0.051 \\
\hline Feed conversion ratio & 4.32 & 4.17 & 4.64 & 0.202 & 0.061 \\
\hline
\end{tabular}

* results are reported as least squares mean; ${ }^{1} \mathrm{C}$, control feed; $\mathrm{L}$, control feed $+3 \%$ extruded linseed; $\mathrm{LO}$, control feed $+3 \%$ extruded linseed $+0.6 \%$ oregano. ${ }^{2}$ SEM: Standard error of means. ${ }^{3}$ BW: Body Weight.

\subsection{Slaughtering and Carcass Traits of Lambs}

Linseed and Linseed + oregano supplementation did not influence the slaughtering data of lambs (Table 5). Other previous studies confirmed that extruded linseed can be an effective ingredient in the diet with no adverse effect on lambs' or kids' performance compared to control diet $[9,12]$.

Table 5. Effect of diet on slaughtering data of lambs *.

\begin{tabular}{|c|c|c|c|c|c|}
\hline \multirow{2}{*}{ Item } & \multicolumn{3}{|c|}{ Dietary Treatment ${ }^{1}$} & \multirow{2}{*}{ SEM $^{2}$} & \multirow{2}{*}{$p$-Value } \\
\hline & $\mathrm{C}$ & L & $\mathrm{L}+\mathrm{O}$ & & \\
\hline Final BW (kg) & 19.65 & 19.13 & 19.30 & 2.234 & 0.564 \\
\hline Slaughter weight $(\mathrm{kg})$ & 18.82 & 18.51 & 18.75 & 2.099 & 0.432 \\
\hline PV netto $(\mathrm{kg})$ & 17.44 & 16.85 & 17.34 & 1.992 & 0.617 \\
\hline Skin + fleece $(\%)$ & 13.13 & 13.24 & 13.84 & 0.867 & 0.265 \\
\hline Hot Carcass dressing $(\%)^{3}$ & 67.72 & 67.09 & 67.94 & 2.457 & 0.745 \\
\hline Cold Carcass dressing (\%) ${ }^{3}$ & 65.73 & 64.75 & 65.82 & 2.800 & 0.889 \\
\hline Right half carcass (kg) & 11.60 & 11.15 & 11.75 & 1.524 & 0.513 \\
\hline \multicolumn{6}{|l|}{ Meat cuts $(\%)^{4}$} \\
\hline Neck & 5.77 & 6.01 & 6.04 & 0.463 & 0.078 \\
\hline Shoulder & 15.34 & 15.83 & 15.41 & 0.785 & 0.124 \\
\hline Leg & 25.67 & 26.33 & 26.38 & 1.040 & 0.525 \\
\hline Steaks & 12.59 & 12.60 & 12.12 & 0.666 & 0.105 \\
\hline Abdominal region & $4.19^{\mathrm{a}}$ & $3.86^{\mathrm{ab}}$ & $3.77^{b}$ & 0.343 & 0.034 \\
\hline Loin & 5.72 & 5.89 & 5.85 & 0.373 & 0.066 \\
\hline Brisket & 7.83 & 7.65 & 7.69 & 0.407 & 0.071 \\
\hline Offal & 8.69 & 8.23 & 8.16 & 0.930 & 0.494 \\
\hline
\end{tabular}

* results are reported as least squares mean; ${ }^{1} \mathrm{C}$, control feed; $\mathrm{L}$, control feed $+3 \%$ extruded linseed; $\mathrm{LO}$, control feed $+3 \%$ extruded linseed $+0.6 \%$ oregano. ${ }^{2}$ SEM: Standard error of means. ${ }^{3} \%$ on body weight; ${ }^{4} \%$ on half carcass weight, means with different letters within each row differ significantly: $\mathrm{a}, \mathrm{b}: p<0.05$.

The percentage of the abdominal region on the right half carcass weight was the only section data that was affected by processing treatment (Table 5): $C$ lambs recorded the highest abdominal region percentage compared to $\mathrm{L}+\mathrm{O}$ lambs $(p=0.034)$.

No effect of feeding extruded linseed and oregano was observed on the main meat cuts; however, the lean proportions of $\mathrm{L}+\mathrm{O}$ lambs' leg (Table 6) reported the highest percentage of lean $(p=0.026)$, while showed a lower percentage of dissectible fat $(p=0.047)$ in comparison to the $L$ group. Previous studies evaluating different natural dietary supplements have shown variable results concerning carcass traits [39,40]. 
Table 6. Dissection data (\% on cut weight) of leg and loin of lambs *.

\begin{tabular}{cccccc}
\hline \multirow{2}{*}{ Item } & \multicolumn{3}{c}{ Dietary Treatment $^{\mathbf{1}}$} & \multirow{2}{*}{ SEM $^{\mathbf{2}}$} & $p$-Value \\
\cline { 2 - 4 } & $\mathbf{C}$ & $\mathbf{L}$ & $\mathbf{L}+\mathbf{O}$ & & \\
\hline Leg (kg) & 0.66 & 0.69 & 0.65 & 0.133 & 0.085 \\
Lean (\%) & $48.24^{\mathrm{b}}$ & $48.04^{\mathrm{b}}$ & $54.27^{\mathrm{a}}$ & 3.953 & 0.026 \\
Dissectible fat (\%) & $15.96^{\mathrm{ab}}$ & $16.42^{\mathrm{a}}$ & $12.88^{\mathrm{b}}$ & 4.219 & 0.047 \\
Bone (\%) & 35.80 & 35.55 & 32.84 & 5.005 & 0.085 \\
Loin (kg) & 2.96 & 2.90 & 3.07 & 0.415 & 0.546 \\
Lean (\%) & 66.88 & 68.34 & 68.69 & 1.866 & 0.081 \\
Dissectible fat (\%) & 9.43 & 8.00 & 7.71 & 1.805 & 0.149 \\
Bone (\%) & 23.69 & 23.66 & 23.59 & 1.466 & 0.142 \\
\hline
\end{tabular}

${ }^{*}$ results are reported as least squares mean; ${ }^{1} \mathrm{C}$, control feed; $\mathrm{L}$, control feed $+3 \%$ extruded linseed; $\mathrm{LO}$, control feed $+3 \%$ extruded linseed $+0.6 \%$ oregano. ${ }^{2}$ SEM: Standard error of means. Means with different letters within each row differ significantly: $p<0.05$.

\subsection{Physical Characteristics of Longissimus Lumborum Muscle of Lambs}

Physical characteristics determined on $\mathrm{Ll}$ muscles are shown in Table 7; muscle $\mathrm{pH}$ at $24 \mathrm{~h}$ post-mortem was affected by diet supplementation showing higher values $(p=0.023)$ on the $\mathrm{L}+\mathrm{O}$ group compared to the $\mathrm{C}$ group (5.47 vs. 5.32). All $\mathrm{pH}_{24}$ value recorded in this trial was lower than $\mathrm{pH}$ founded by Marcon et al. [41], Pena-Bermudez et al. [42], and Rant et al. [43]. Meat color features were quite similar among the three supplementations studied, except for the $\mathrm{a}^{*}$ index where the L group showed $(p=0.049)$ the lowest red value compared to the L + O group (10.42 vs. 9.41), while Rant et al. [43] and Marino et al. [44] recorded the intermediate value.

Table 7. Meat characteristics from Longissimus lumborum muscle *.

\begin{tabular}{|c|c|c|c|c|c|}
\hline \multirow{2}{*}{ Item } & \multicolumn{3}{|c|}{ Dietary Treatment ${ }^{1}$} & \multirow{2}{*}{ SEM $^{2}$} & \multirow{2}{*}{$p$-Value } \\
\hline & $\mathrm{C}$ & $\mathbf{L}$ & $\mathbf{L}+\mathbf{O}$ & & \\
\hline $\mathrm{pH}_{1} \#$ & 6.56 & 6.53 & 6.55 & 0.159 & 0.052 \\
\hline $\mathrm{pH}_{24} \# \#$ & $5.32^{b}$ & $5.40^{a b}$ & $5.47^{\mathrm{a}}$ & 0.089 & 0.023 \\
\hline $\mathrm{L}^{*}$ & 41.40 & 41.86 & 40.26 & 2.771 & 0.761 \\
\hline$a^{*}$ & $9.73^{a b}$ & $9.41^{\mathrm{b}}$ & $10.42^{\mathrm{a}}$ & 1.013 & 0.049 \\
\hline$b^{*}$ & 11.67 & 11.36 & 11.37 & 1.279 & 0.963 \\
\hline WBS, $\mathrm{kg} / \mathrm{cm}^{2}$ & 2.03 & 2.40 & 2.19 & 0.534 & 0.776 \\
\hline T-BARS (mg MDA/kg meat) & 0.318 & 0.382 & 0.371 & 0.122 & 0.066 \\
\hline
\end{tabular}

* results are reported as least squares mean; ${ }^{1} \mathrm{C}$, control feed; $\mathrm{L}$, control feed $+3 \%$ extruded linseed; LO, control feed $+3 \%$ extruded linseed $+0.6 \%$ oregano. ${ }^{2}$ SEM: Standard error of means. ${ }^{\#} \mathrm{pH}_{1}$ at $1 \mathrm{~h}$ post-mortem; ${ }^{\# \#} \mathrm{pH}_{24}$ at $24 \mathrm{~h}$ post-mortem; $\mathrm{L}^{*}$, Lightness; $\mathrm{a}^{*}$, redness; $\mathrm{b}^{*}$ yellowness; WBS, Warner-Bratzler shear force; means with different letters within each row differ significantly: $\mathrm{a}, \mathrm{b}: p<0.05$.

T-BARS values ( $\mathrm{mg}$ of malondialdehyde-MDA $/ \mathrm{kg}$ meat) showed were similar for Linseed and Linseed + oregano group; this result can explain the use of linseed, which makes the meat easier to oxidize [42].

\subsection{Chemical Composition of Longissimus Lumborum Muscle of Lambs}

Dietary treatments had no significant effect $(p>0.05)$ on Longissimus lumborum chemical composition (Table 8), as Fusaro et al. [45] didn't show the effects of dam dietary treatment on the chemical composition of the suckling lamb Longissimus lumborum. 
Table 8. Chemical composition (\%) from Longissimus lumborum muscle *.

\begin{tabular}{cccccc}
\hline \multirow{2}{*}{ Item } & \multicolumn{3}{c}{ Dietary Treatment $^{\mathbf{1}}$} & \multirow{2}{*}{ SEM $^{\mathbf{2}}$} & $\boldsymbol{p}$-Value \\
\cline { 2 - 4 } & $\mathbf{C}$ & $\mathbf{L}$ & $\mathbf{L}+\mathbf{O}$ & & \\
\hline Moisture & 75.06 & 75.67 & 74.91 & 0.638 & 0.084 \\
Protein & 19.17 & 19.05 & 19.55 & 0.652 & 0.070 \\
Lipid & 3.68 & 3.60 & 3.50 & 0.838 & 0.055 \\
Ash & 1.13 & 1.12 & 1.15 & 0.067 & 0.095 \\
\hline
\end{tabular}

${ }^{*}$ results are reported as least squares mean; ${ }^{1} \mathrm{C}$, control feed; $\mathrm{L}$, control feed $+3 \%$ extruded linseed; LO, control feed $+3 \%$ extruded linseed $+0.6 \%$ oregano. ${ }^{2}$ SEM: Standard error of means.

\subsection{Fatty Acid Composition of Longissimus Lumborum Muscle of Lambs}

Table 9 shows the effect of lamb dietary treatment on the FA composition of lamb Longissimus lumborum. The results showed that linseed supplementation lowers SFA levels $(p=0.039)$, especially C14:0 $(p=0.005)$, while $\mathrm{L}+\mathrm{O}$ supplementation showed a lower value of $\mathrm{C} 12: 0(p=0.044)$ compared to $C$, which is desirable because these FA are hypercholesterolemic and are associated with a higher risk of cardiovascular disease and type 2 diabetes [46,47]. Our results are consistent with those of Fusaro et al. [45] and Miltko et al. [46], who observed a greater decrease in SFA concentrations in intramuscular fat of lambs sucking ewe that received diet supplementation with linseed oil than in the control diet. On the other hand, Giannico et al. [8], shows an increase of SFA level in the Gentile di Puglia intramuscular fat of lambs fed with linseed oil and extruded linseed integration compared with lambs fed with soybean oil.

Dietary treatments had a not significant effect on Longissimus lumborum MUFA composition; only C16:1 showed a lower value $(p=0.048)$ in intramuscular fat of L lambs in comparison to $C$ lambs $(0.56 \%$ vs. $1.58 \%)$. Our results are in agreement with those reported by other authors $[8,44,45,48,49]$.

In our experiment, the lambs in groups $\mathrm{L}$ and $\mathrm{L}+\mathrm{O}$ exhibited higher percentages of linoleic acid $(p=0.005), \alpha$-linolenic acid $(p=0.001)$, and eicosapentaenoic acid-EPA $(p=0.003)$ than the animals in group $C$ and the same results are showed by Giannico et al. [8] and Fusaro et al. [45] papers. The conversion capacity of $\alpha$-linolenic to healthpromoting long-chain n-3 PUFA is limited in humans [47], which reinforces the significance of its dietary supply. The increase in the concentration of long-chain n-3 PUFA coincided with an increase in dietary C18:3 n-3 concentration of linseed rations.

The meat FA profile was similar to the FA composition of feed, and it was not surprising that changes in feed FA composition can induce significant differences in the FA profile of meat and fat deposit in young lambs. In the young lambs, the essential FAs were incorporated directly into the muscle rather than being stored in the adipose tissue, which is considered an important metabolic role [45].

The $n-6 / n-3$ ratio is used to evaluate the nutritional value of fat for human consumption, and this ratio is strongly dependent on the FA profile of the ration fed to ruminants. This ratio is particularly beneficial in the meat of ruminants that consume forages or oilseed with an increased C18:3 content [47]. Lowering the $n-6 / n: 3$ coefficients in food production has been recommended to prevent or modulate certain human diseases, and it should range between 1 and 4 [50]. Our results were within this range; the n:6/n:3 ratios found in the $\mathrm{L}$ and $\mathrm{L}+\mathrm{O}$ groups are the lowest. The same results are showed by Gómez-Cortés et al. [51] and Rotondi et al. [12] that found a lower n-6/n-3 ratio in the meat of animal fed linseed.

The indices of atherogenicity and of thrombogenicity are indicators assessing the level and the interrelation of some fatty acids that have effects on the occurrence of coronary heart diseases [33]. In this study, the meat of control group lambs showed a markedly greater atherogenic $(p=0.041)$ and thrombogenic $(p=0.039)$ index compared to the other two groups. The same effect of linseed in the diet is showed by Fusaro et al. [45], and also their results are not statistically significant. 
Table 9. Fatty acid composition (\% total FA methyl esters) of lamb meat from Longissimus lumborum muscle*.

\begin{tabular}{|c|c|c|c|c|c|}
\hline \multirow{2}{*}{ Item } & \multicolumn{3}{|c|}{ Dietary Treatment $^{1}$} & \multirow{2}{*}{ SEM $^{2}$} & \multirow{2}{*}{$p$-Value } \\
\hline & $\mathrm{C}$ & $\mathbf{L}$ & $\mathrm{L}+\mathrm{O}$ & & \\
\hline Total Fatty acids (g/100 g muscle) & 3.26 & 3.18 & 3.10 & 0.241 & 0.304 \\
\hline C10:0 (capric) & 0.37 & 0.36 & 0.31 & 0.220 & 0.256 \\
\hline C12:0 (lauric) & $3.52^{\mathrm{a}}$ & $3.00^{\mathrm{ab}}$ & $2.87^{\mathrm{b}}$ & 0.592 & 0.044 \\
\hline C14:0 (myristic) & $3.42^{\mathrm{A}}$ & $2.33^{B}$ & $2.74 \mathrm{AB}$ & 0.758 & 0.005 \\
\hline $\mathrm{C} 15: 0$ & 0.07 & 0.08 & 0.05 & 0.115 & 0.074 \\
\hline C16:0 (palmitic) & 23.92 & 23.16 & 22.00 & 2.850 & 0.075 \\
\hline C17:0 & $0.56^{\mathrm{B}}$ & $1.56^{\mathrm{Aa}}$ & $0.80^{b}$ & 0.415 & 0.003 \\
\hline C18:0 (stearic) & 14.94 & 13.96 & 14.81 & 1.492 & 0.063 \\
\hline C20:0 & 1.07 & 1.81 & 1.46 & 0.613 & 0.535 \\
\hline$\sum \mathrm{SFA}$ & $50.99^{a}$ & $48.70^{b}$ & $47.38^{b}$ & 2.279 & 0.039 \\
\hline C14:1 & 0.50 & 0.69 & 0.45 & 0.492 & 0.456 \\
\hline $\mathrm{C} 15: 1$ & 0.08 & 0.09 & 0.10 & 0.076 & 0.189 \\
\hline C16:1 n7 (palmitoleic) & $1.58^{\mathrm{a}}$ & $0.56^{\mathrm{b}}$ & $1.52^{\mathrm{ab}}$ & 0.326 & 0.048 \\
\hline C17:1 & 0.17 & 0.28 & 0.14 & 0.160 & 0.401 \\
\hline C18:1 n9 trans (elaidic) & 3.16 & 3.02 & 3.31 & 1.444 & 0.155 \\
\hline C18:1 n9 cis (oleic) & 34.71 & 34.72 & 34.60 & 2.461 & 0.087 \\
\hline$\sum$ MUFA & 40.48 & 39.43 & 40.62 & 2.801 & 0.062 \\
\hline C18:2 n6 c9 c12 (linoleic) & $5.99^{\mathrm{B}}$ & $7.82^{\mathrm{A}}$ & $8.06^{\mathrm{A}}$ & 1.124 & 0.005 \\
\hline CLA c9, t11 & 0.86 & 0.97 & 0.87 & 0.229 & 0.218 \\
\hline CLA t10, c12 & 0.32 & 0.34 & 0.39 & 0.238 & 0.165 \\
\hline C18:3n3 ( $\alpha$-linolenic) & $0.41^{\mathrm{B}}$ & $0.70^{\mathrm{A}}$ & $0.71^{\mathrm{A}}$ & 0.071 & 0.001 \\
\hline C20:4 n6 (ARA) & 0.17 & 0.12 & 0.13 & 0.073 & 0.316 \\
\hline C20:5 n3 (EPA) & $0.09^{\mathrm{B}}$ & $0.21^{\mathrm{A}}$ & $0.19^{\mathrm{A}}$ & 0.024 & 0.003 \\
\hline C22:5 n3 (DPA) & 0.01 & 0.05 & 0.13 & 0.186 & 0.240 \\
\hline C22:6 n3 (DHA) & 0.30 & 0.50 & 0.62 & 0.410 & 0.155 \\
\hline$\sum$ PUFA & $8.53^{\mathrm{B}}$ & $11.86^{\mathrm{A}}$ & $11.99 \mathrm{~A}$ & 1.431 & 0.007 \\
\hline$\sum$ UFA & $49.01^{\mathrm{b}}$ & $51.30^{\mathrm{ab}}$ & $52.62^{\mathrm{a}}$ & 2.279 & 0.032 \\
\hline n-6 & $7.32^{\mathrm{B}}$ & $9.14^{\mathrm{A}}$ & $9.45^{\mathrm{A}}$ & 1.075 & 0.001 \\
\hline n-3 & $0.90^{\mathrm{b}}$ & $2.26^{\mathrm{a}}$ & $1.85^{\mathrm{ab}}$ & 1.059 & 0.034 \\
\hline$n-6 / n-3$ & $8.70^{\mathrm{A}}$ & $5.24^{\mathrm{B}}$ & $5.51^{\mathrm{B}}$ & 2.152 & 0.002 \\
\hline A.I. & $0.85^{\mathrm{a}}$ & $0.70^{b}$ & $0.69^{b}$ & 0.113 & 0.031 \\
\hline T.I. & $1.58^{\mathrm{a}}$ & $1.29^{b}$ & $1.29^{b}$ & 0.218 & 0.029 \\
\hline
\end{tabular}

* results are reported as least squares mean; ${ }^{1} \mathrm{C}$, control feed; $\mathrm{L}$, control feed $+3 \%$ extruded linseed; $\mathrm{LO}$, control feed $+3 \%$ extruded linseed $+0.6 \%$ oregano. ${ }^{2}$ SEM: Standard error of means. SFA-saturated fatty acids (sum of $\mathrm{C} 10: 0+\mathrm{C} 12: 0+\mathrm{C} 14: 0+\mathrm{C} 15: 0+\mathrm{C} 16: 0+\mathrm{C} 17: 0+\mathrm{C} 18: 0+\mathrm{C} 21: 0+\mathrm{C} 22: 0+\mathrm{C} 24: 0) ;$ MUFA - monounsaturated fatty acids (sum of C14:1 + C15:1 + C16:1 c9 + C17:1 c10+C18:1 t11 + C18:1 t9 + C18:1 t10 + C18:1 c9 + C20:1 + C24:1); Total n-6 (sum of C18:2 c9; 12 + C18:2 c9; t11 + C18:3 + C20:3 +C20:4); Total n-3 (sum of C18:3 + C20:3 + C20:4 + C20:5 + C22:6); PUFA - polyunsaturated fatty acids (sum of $n-6+n-3)$; means with different letters within each row differ significantly: $\mathrm{a}, \mathrm{b}:(p<0.05) ; \mathrm{A}, \mathrm{B}:(p<0.01)$.

\subsection{Sensory Analysis of Longissimus Lumborum Muscle of Lambs}

Sensory analysis results of $\mathrm{Ll}$ muscle in Gentile di Puglia lambs, according to feed, are shown in Table 10. Several studies show that the taste of sheep meat is influenced by the animal's diet; meat from animals fed with concentrate shows higher flavor intensity than that of grazing sheep [52-54]. We found similar results in this study; the linseed and oregano supplementation influenced the judges' evaluation. The meat from the $\mathrm{L}+\mathrm{O}$ lambs were tender $(p=0.007)$ and juicy $(p=0.006)$ then the meat of lambs of the other two group; while $\mathrm{L}+\mathrm{O}$ meat was succulent $(p=0.008)$ then the $\mathrm{C}$ lambs' meat, it was also more flavorful ( $p=0.048)$ compared with L meat (5.56 vs. 4.56$)$. 
Table 10. Sensory analysis of meat from the Longissimus lumborum muscle *

\begin{tabular}{|c|c|c|c|c|c|}
\hline \multirow{2}{*}{ Item } & \multicolumn{3}{|c|}{ Dietary Treatment ${ }^{1}$} & \multirow{2}{*}{ SEM $^{2}$} & \multirow{2}{*}{$p$-Value } \\
\hline & $\mathrm{C}$ & $\mathbf{L}$ & $\mathrm{L}+\mathrm{O}$ & & \\
\hline Judge $(n)$ & 41 & 41 & 41 & & \\
\hline Meat Flavor & $4.90^{\mathrm{ab}}$ & $4.56^{\mathrm{b}}$ & $5.56^{\mathrm{a}}$ & 2.243 & 0.048 \\
\hline Succulence & $4.80^{\mathrm{B}}$ & $5.21 \mathrm{AB}$ & $5.87^{\mathrm{A}}$ & 1.788 & 0.008 \\
\hline Tenderness & $6.95^{B}$ & $6.82^{\mathrm{B}}$ & $7.73^{\mathrm{A}}$ & 1.548 & 0.007 \\
\hline Juiciness & $6.22^{\mathrm{B}}$ & $6.37^{\mathrm{B}}$ & $7.41^{\mathrm{A}}$ & 1.506 & 0.006 \\
\hline Overall acceptance & 7.21 & 7.20 & 7.32 & 1.196 & 0.078 \\
\hline
\end{tabular}

* results are reported as least squares mean; ${ }^{1} \mathrm{C}$, control feed; $\mathrm{L}$, control feed $+3 \%$ extruded linseed; LO, control feed $+3 \%$ extruded linseed $+0.6 \%$ oregano. ${ }^{2}$ SEM: Standard error of means; means with different letters within each row differ significantly: $\mathrm{a}, \mathrm{b}:(p<0.05), \mathrm{A}, \mathrm{B}:(p<0.01)$.

For overall acceptability, the sum of descriptors contributing to the acceptance of the lamb meat ranged from 7.20 to 7.32 , indicating that the meat has good acceptance.

\section{Conclusions}

This paper contributes to a better understanding of the meat quality and potential health benefits of FA profiles in native Italian sheep breeds fed with linseed supplementation. According to the results of the present study, linseed and linseed + oregano supplementation did not influence growth and feed intake of lambs, or their slaughtering and carcass traits. These supplementations did not change physical characteristics or chemical composition of lambs' meat.

As expected, FA profile in $\mathrm{Ll}$ muscle was affected by linseed and linseed + oregano supplemented to lamb diets, in fact, $\mathrm{L}$ and $\mathrm{L}+\mathrm{O}$ meats showed the lowest value of healthy parameters, such as the n- $6 / \mathrm{n}-3$ ratio, atherogenic and thrombogenic indexes. Additionally, the supplementation of linseed to diets seems to reduce the concentration of lauric and myristic acid and the total SFA; instead, linseed supplementation increase the concentration of total n-3 PUFA, particularly $\alpha$-linolenic and EPA. Linseed and oregano tended to reduce the SFA percentage, significantly increased the PUFA and UFA concentration, particularly the linoleic acid, $\alpha$-linolenic, and total n-6 PUFA.

Linseed and oregano supplementation to the diet of lambs improve meat flavor and overall acceptance by consumers, as has been seen in succulence, tenderness, and juiciness valuation.

These positive results in terms of potential benefits for human health and consumers acceptance of Gentile di Puglia lambs may represent an opportunity for valorization and promotion of this breed. Further trials will be conducted with the use of other officinal plants rich in antioxidants.

Author Contributions: Conceptualization, M.R. and S.T.; methodology, G.S.; formal analysis and investigation, G.S.; data curation, S.T.; writing-original draft preparation, writing—review and editing, S.T. and M.R.; visualization, S.T.; supervision, M.R. All authors have read and agreed to the published version of the manuscript.

Funding: The present research was part of the project founded and supported by the Basilicata Region, Italy “VAL.BI.OVI.CAP.-PSR Basilicata 2014-2020-Misura 10-Sottomisura 10.2 -Sostegno per la conservazione, l'uso e lo sviluppo sostenibili delle risorse genetiche in agricoltura".

Institutional Review Board Statement: Ethical review and approval were waived for this study, due to animals were cared for and handled in compliance with the EU legislation on animal welfare regulations (Directive 2010/63/EU which updates and replaces the 1986 Directive 86/609/EEC on the protection of animals used for scientific purposes) and following the University research polices.

Data Availability Statement: All data generated or analyzed during this study are included in this article. 
Acknowledgments: The authors express their gratitude to the technicians of the Department of Agricultural and Environmental Science Massimo Lacitignola, Dott. Nicolò Devito and Dott. Domenico Gerardi for their laboratory assistance.

Conflicts of Interest: The authors declare no conflict of interest.

\section{References}

1. Mascheroni, E. Zootecnia Speciale; UTET: Torino, Italy, 1927.

2. AIA (Italian Breeders Association). Allevamenti Italiani Ovini; REDA: Roma, Italy, 1961.

3. EUROPEAN COMMISSION. Council Regulation of 30 September 2000 on support for rural development form the European Agricultural Guidance and Guarantee Fund, 1257/99/EC. In Official Journal of the European Commission; EUROPEAN COMMISSION: Brussels, Belgium, 2004. Available online: https:/ / eur-lex.europa.eu/LexUriServ/LexUriServ.do?uri=OJ:L:2004:153:0030: 0081:EN:PDF (accessed on 21 December 2020).

4. ASSONAPA. Available online: WwW.assonapa.it (accessed on 4 January 2021).

5. Wyness, L.; Weichselbaum, E.; O'Connor, A.; Williams, E.B.; Benelam, B.; Riley, H.; Stanner, S. Red meat in the diet: An update. Nutr. Bull. 2011, 36, 34-77. [CrossRef]

6. Givens, D.I. The role of animal nutrition in improving the nutritive value of animal-derived foods in relation to chronic disease. Proc. Nutr. Soc. 2005, 64, 395-402. [CrossRef] [PubMed]

7. Sinclair, L.A. Nutritional manipulation of the fatty acid composition of sheep meat: A review. J. Agric. Sci. 2007, 145, 419-434. [CrossRef]

8. Giannico, F.; Colonna, M.A.; Coluccia, A.; Crocco, D.; Vonghia, G.; Cocca, C.; Jambrenghi, A.C. Extruded linseed and linseed oil as alternative to soybean meal and soybean oil in diets for fattening lambs. Ital. J. Anim. Sci. 2009, 8, 495-497. [CrossRef]

9. Colonna, M.A.; Giannico, F.; Coluccia, A.; Di Bello, G.; Vonghia, G.; Caputi Jambrenghi, A. Dietary supplementation with extruded linseed and linseed oil in lamb feeding: Productive performances and meat quality traits. Progr. Nutr. 2011, 13, 111-124.

10. Toteda, F.; Facciolongo, A.; Ragni, M.; Vicenti, A. Effect of suckling type and PUFA use on productive performances, quantiqualitative characteristics of meat and fatty acid profile in lamb. Prog. Nutr. 2011, 13, 125-134.

11. Facciolongo, A.; Lestingi, A.; Colonna, M.; Nicastro, F.; De Marzo, D.; Toteda, F. Effect of diet lipid source (linseed vs. soybean) and gender on performance, meat quality and intramuscular fatty acid composition in fattening lambs. Small Rumin. Res. 2018, 159, 11-17. [CrossRef]

12. Rotondi, P.; Colonna, M.A.; Marsico, G.; Giannico, F.; Ragni, M.; Facciolongo, A.M. Dietary Supplementation with Oregano and Linseed in Garganica Suckling Kids: Effects on Growth Performances and Meat Quality. Pak. J. Zool. 2018, 50, 1421. [CrossRef]

13. Tarricone, S.; Giannico, F.; Ragni, M.; Colonna, M.A.; Rotondi, P.; Cosentino, C.; Tufarelli, V.; Laudadio, V. Effects of dietary extruded linseed (Linum usitatissimum L.) and oregano (Origanum vulgare) on growth traits, carcass composition and meat quality of Grigia di Potenza suckling kids. Intern. J. Agric. And Biol. 2021, in press.

14. Ragni, M.; Toteda, F.; Tufarelli, V.; Laudadio, V.; Facciolongo, A.M.; Dipalo, F.; Vicenti, A. Feeding of extruded flaxseed (Linum usitatissimum L.) and pasture in Podolica young bulls: Effects on growth traits, meat quality and fatty acid composition. Pak. J. Zool. 2014, 46, 1101-1109.

15. Tarricone, S.; Colonna, M.; Giannico, F.; Facciolongo, A.; Jambrenghi, A.C.; Ragni, M. Effects of dietary extruded linseed (Linum usitatissimum L.) on performance and meat quality in Podolian young bulls. S. Afr. J. Anim. Sci. 2019, 49, 781. [CrossRef]

16. Tarricone, S.; Colonna, M.; Giannico, F.; Ragni, M.; Lestingi, A.; Facciolongo, A. Effect of an extruded linseed diet on meat quality traits in Nero Lucano pigs. S. Afr. J. Anim. Sci. 2020, 49, 1093-1103. [CrossRef]

17. Wood, J.; Richardson, R.; Nute, G.; Fisher, A.; Campo, M.; Kasapidou, E.; Sheard, P.; Enser, M. Effects of fatty acids on meat quality: A review. Meat Sci. 2004, 66, 21-32. [CrossRef]

18. Cimmino, R.; Barone, C.M.A.; Claps, S.; Varricchio, E.; Rufrano, D.; Caroprese, M.; Albenzio, M.; De Palo, P.; Campanile, G.; Neglia, G. Effects of dietary supplementation with polyphenols on meat quality in Saanen goat kids. BMC Veter- Res. 2018, 14, 181. [CrossRef] [PubMed]

19. Cosentino, C.; Colonna, M.; Musto, M.; Dimotta, A.; Freschi, P.; Tarricone, S.; Ragni, M.; Paolino, R. Effects of dietary supplementation with extruded linseed and oregano in autochthonous goat breeds on the fatty acid profile of milk and quality of Padraccio cheese. J. Dairy Sci. 2021, 104, 1445-1453. [CrossRef] [PubMed]

20. Ahmad, S.R.; Gokulakrishnan, P.; Giriprasad, R.; Yatoo, A. Fruit-based natural antioxidants in meat and meat products: A re-view. Crit. Rev. Food Sci. Nutr. 2015, 55, 1503-1513. [CrossRef] [PubMed]

21. Vital, A.C.P.; Guerrero, A.; Kempinski, E.M.B.C.; Monteschio, J.D.O.; Sary, C.; Ramos, T.R.; Campo, M.D.M.; Prado, I.N.D. Consumer profile and acceptability of cooked beef steaks with edible and active coating containing oregano and rosemary essential oils. Meat Sci. 2018, 143, 153-158. [CrossRef] [PubMed]

22. Tufarelli, V.; Casalino, E.; D’alessandro, A.G.; Laudadio, V.; Tufarelli, E.C.V. Dietary Phenolic Compounds: Biochemistry, Metabolism and Significance in Animal and Human Health. Curr. Drug Metab. 2018, 18, 905-913. [CrossRef] [PubMed]

23. Lambert, R.; Skandamis, P.; Coote, P.; Nychas, G.-J. A study of the minimum inhibitory concentration and mode of action of oregano essential oil, thymol and carvacrol. J. Appl. Microbiol. 2001, 91, 453-462. [CrossRef] [PubMed]

24. Yanishlieva-Maslarova, N.V. Inhibiting oxidation. In Antioxidants in Food: Practical Applications; Pokorny, J., Yanishlieva, N., Gordon, M., Eds.; Woodhead Publishing Limited, CRC Press: Cambridge, UK, 2001; pp. 22-70. 
25. Bampidis, V.; Christodoulou, V.; Florou-Paneri, P.; Christaki, E.; Spais, A.; Chatzopoulou, P. Effect of dietary dried oregano leaves supplementation on performance and carcass characteristics of growing lambs. Anim. Feed. Sci. Technol. 2005, 121, 285-295. [CrossRef]

26. Simitzis, P.; Deligeorgis, S.; Bizelis, J.; Dardamani, A.; Theodosiou, I.; Fegeros, K. Effect of dietary oregano oil supplementation on lamb meat characteristics. Meat Sci. 2008, 79, 217-223. [CrossRef]

27. National Research Council. Nutrient Requirements of Small Ruminants: Sheep, Goats, Cervids and New World Camelids; The National Academy Press: Washington, DC, USA, 2007.

28. Lestingi, A.; Facciolongo, A.; Jambrenghi, A.; Ragni, M.; Toteda, F. The use of peas and sweet lupin seeds alone or in association for fattening lambs: Effects on performance, blood parameters and meat quality. Small Rumin. Res. 2016, 143, 15-23. [CrossRef]

29. Association of Official Agricultural Chemistry. Official Methods of Analysis of the AOAC, 17th ed.; Association of Official Ana-lytical Chemists: Arlington, VA, USA, 2000.

30. Sauvant, D.; Perez, J.M.; Tran, G. Table od Composition and Nutritional Value of Feed Materials: Pigs, Poultry, Cattle, Sheep, Goats, Rabbits, Horses and Fish, 1st ed.; Wageningen Academic Publisher: Wageningen, The Netherlands, 2004.

31. Šicklep, M.; Candek-Potokar, M. Pork color measurements as affected by bloom time and measurement location. J. Muscle Foods 2007, 18, 78-87.

32. Folch, J.; Lees, M.; Stanley, G.S. A simple method for the isolation and purification of total lipids from animal tissues. J. Biol. Chem. 1957, 226, 497-509. [CrossRef]

33. Christie, W.W. Lipid Analysis-Isolation, Separation, Identification and Structural Analysis of Lipids; Pergamon: Oxford, UK, 1982; p. 270.

34. Ulbricht, T.L.V.; Southgate, D.A.T. Coronary heart disease: Seven dietary factors. Lancet 1991, 338, 985-992. [CrossRef]

35. Colonna, M.A.; Rotondi, P.; Selvaggi, M.; Jambrenghi, A.C.; Ragni, M.; Tarricone, S. Sustainable Rearing for Kid Meat Production in Southern Italy Marginal Areas: A Comparison among Three Genotypes. Sustainability 2020, 12, 6922. [CrossRef]

36. Landim, A.V.; Castanheira, M.; Fioravanti, M.C.S.; Pacheco, A.; Cardoso, M.T.M.; Louvandini, H.; McManus, C.; Pimentel, C. Physical, chemical and sensorial parameters for lambs of different groups, slaughtered at different weights. Trop. Anim. Heal. Prod. 2011, 43, 1089-1096. [CrossRef] [PubMed]

37. SAS. SAS/STAT 9.13 User's Guide; Statistical Analysis System Inst.: Cary, NC, USA, 2004.

38. Lestingi, A.; Colonna, M.; Marsico, G.; Tarricone, S.; Facciolongo, A. Effects of legume seeds and processing treatment on growth, carcass traits and blood constituents of fattening lambs. S. Afr. J. Anim. Sci. 2019, 49, 799. [CrossRef]

39. Facciolongo, A.M.; Rubino, G.; Zarrilli, A.; Vicenti, A.; Ragni, M.; Toteda, F. Alternative protein sources in lamb feeding 1. Effects on productive performances, carcass characteristics and energy and protein metabolism. Progr. in Nutr. 2014, 16, 105-115.

40. Colonna, M.A.; Giannico, F.; Marsico, G.; Vonghia, G.; Ragni, M.; Jambrenghi, A.C. Effect of pea (Pisum sativum L.) as alter-native to soybean meal on the productive performances and meat quality traits of Merino crossbred lamb types. Progr. Nutr. 2014, 16, 39-51.

41. Marcon, H.; Souza, C.F.; Baldissera, M.D.; Alba, D.F.; Favaretto, J.A.; Santos, D.S.; Borges, L.; Kessler, J.D.; Vedovatto, M.; Bianchi, A.E.; et al. Effect of curcumin dietary supplementation on growth performance, physiology, carcass characteristics and meat quality in lambs. Ann. Anim. Sci. 2020. [CrossRef]

42. Pena-Bermudez, Y.A.; Lobo, R.R.; Rojas-Moreno, D.A.; Poleti, M.D.; De Amorim, T.R.; Rosa, A.F.; Pereira, A.S.C.; Pinheiro, R.S.B.; Bueno, I.C.S. Effects of Feeding Increasing Levels of Yerba Mate on Lamb Meat Quality and Antioxidant Activity. Animals 2020, 10, 1458. [CrossRef] [PubMed]

43. Rant, W.; Radzik-Rant, A.; Świątek, M.; Niżnikowski, R.; Szymańska, Ż.; Bednarczyk, M.; Orłowski, E.; Morales-Villavicencio, A.; Ślęzak, M. The effect of aging and muscle type on the quality characteristics and lipid oxidation of lamb meat. Arch. Anim. Breed. 2019, 62, 383-391. [CrossRef]

44. Marino, R.; Caroprese, M.; Annicchiarico, G.; Ciampi, F.; Ciliberti, M.G.; Della Malva, A.; Santillo, A.; Sevi, A.; Albenzio, M. Effect of Diet Supplementation with Quinoa Seed and/or Linseed on Immune Response, Productivity and Meat Quality in Merinos Derived Lambs. Animals 2018, 8, 204. [CrossRef] [PubMed]

45. Fusaro, I.; Giammarco, M.; Chincarini, M.; Vaintrub, M.O.; Palmonari, A.; Mammi, L.M.E.; Formigoni, A.; Di Giuseppe, L.; Vignola, G. Effect of Ewe Diet on Milk and Muscle Fatty Acid Composition of Suckling Lambs of the Protected Geographical Origin Abbacchio Romano. Animals 2019, 10, 25. [CrossRef] [PubMed]

46. Miltko, R.; Majewska, M.P.; Bełżecki, G.; Kula, K.; Kowalik, B. Growth performance, carcass and meat quality of lambs supplemented different vegetable oils. Asian-Australas. J. Anim. Sci. 2019, 32, 767-775. [CrossRef] [PubMed]

47. Chikwanha, O.C.; Vahmani, P.; Muchenje, V.; Dugan, M.E.R.; Mapiye, C. Nutritional enhancement of sheep meat fatty acid profile for human health and wellbeing. Food Res. Int. 2018, 104, 25-38. [CrossRef] [PubMed]

48. Facciolongo, A.M.; De Marzo, D.; Ragni, M.; Lestingi, A.; Toteda, F. Use of alternative protein sources for finishing lambs. 2. Effects on chemical and physical characteristics and fatty acid composition of meat. Progr. Nutr. 2015, 17, 165-173.

49. Atti, N.; Methlouthi, N.; Saidi, C.; Mahouachi, M. Effects of extruded linseed on muscle physicochemical characteristics and fatty acid composition of lambs. J. Appl. Anim. Res. 2013, 41, 404-409. [CrossRef]

50. WHO/FAO (World Health Organization/Food and Agriculture Organization). Diet, Nutrition and the Prevention of Chronic Diseases; WHO Technical Report Series; WHO: Geneva, Switzerland, 2003. 
51. Gómez-Cortés, P.; Frutos, P.; Mantecon, A.R.; Juarez, M.; De La Fuente, M.; Hervás, G. Milk Production, Conjugated Linoleic Acid Content, and In Vitro Ruminal Fermentation in Response to High Levels of Soybean Oil in Dairy Ewe Diet. J. Dairy Sci. 2008, 91, 1560-1569. [CrossRef]

52. Priolo, A.; Micol, D.; Agabriel, J.; Prache, S.; Dransfield, E. Effect of grass or concentrate feeding systems on lamb carcass and meat quality. Meat Sci. 2002, 62, 179-185. [CrossRef]

53. Borton, R.J.; Loerch, S.C.; McClure, K.E.; Wulf, D.M. Comparison of characteristics of lambs fed concentrate or grazed on ryegrass to traditional or heavy slaughter weights. I. Production, carcass, and organoleptic characteristics1. J. Anim. Sci. 2005, 83, 679-685. [CrossRef] [PubMed]

54. Resconi, V.; Campo, M.; I Furnols, M.F.; Montossi, F.; Sanudo, C. Sensory evaluation of castrated lambs finished on different proportions of pasture and concentrate feeding systems. Meat Sci. 2009, 83, 31-37. [CrossRef] [PubMed] 